\title{
Over-Expression of $\mathrm{Na} / \mathrm{Ca}$ Exchangers in Soft Tissues as a Novel Diagnostic Marker for Carcinogenesis
}

\author{
Yerazik Mikaelyan and Sinerik Ayrapetyan* \\ UNESCO Chair in Life Sciences, Life Sciences International Postgraduate Educational Center, Yerevan, Armenia
}

${ }^{*}$ Corresponding author: Sinerik Ayrapetyan, UNESCO Chair-Life Sciences International Postgraduate Educational Center, Yerevan, Armenia, Tel: +374 10 624170; E-mail: info@biophys.am, life@biophys.am

Received: 17 Jan, 2019 | Accepted: 24 Jan, 2019 | Published: 30 Jan, 2019

Citation: Mikaelyan Y, Ayrapetyan S (2019) Over-Expression of Na/Ca Exchangers in Soft Tissues as a Novel Diagnostic Marker for Carcinogenesis. Int J Cancer Res Mol Mech 5(1): dx.doi.org/10.16966/2381-3318.142

Copyright: (C) 2019 Mikaelyan Y, et al. This is an open-access article distributed under the terms of the Creative Commons Attribution License, which permits unrestricted use, distribution, and reproduction in any medium, provided the original author and source are credited.

\begin{abstract}
The dysfunction of metabolic control of cell hydration is a common consequence of cell pathology. Thus, the cell over-hydration serves as a diagnostic marker for carcinogenesis, while cell dehydration-as a marker for nerve and cardiovascular disorders. From these data it is followed that different metabolic pathways control cell hydration in excitable and soft tissues. From the diagnostic point of view, it is important to evaluate which of these two tissue hydration types is more sensitive to pathology of organism, including carcinogenesis.

Previously, we have shown that the activation of $\mathrm{Na} / \mathrm{Ca}$ exchange in the reverse mode leading to cell dehydration serves as a primary mechanism for ageing-induced neuronal and cardiovascular disorders. However, the role of $\mathrm{Na} / \mathrm{Ca}$ exchange in the reverse mode in the regulation of cell hydration in soft tissues of healthy and tumor carrying animals is not clearly identified yet. For this purpose, the comparative study of cell hydration, $\left[{ }^{3} \mathrm{H}\right]$-ouabain binding with the cell membrane, the ${ }^{45} \mathrm{Ca}^{2+}$ uptake and intracellular cAMP contents in brain cortex and spleen tissues in healthy and sarcoma-180 tumor carrying mice is performed. The obtained data bring us to the conclusion that in the spleen tissues of tumor carrying mice there is over-expression of cAMP-activated $\mathrm{Na} / \mathrm{Ca}$ exchangers in the reverse mode in the cell membrane, which leads to over-hydration of the spleen tissues as a result of stimulation of endogenous water molecule formation by the intracellular $\mathrm{Ca}^{2+}$-induced stimulation of mitochondrial oxidative processes. It is suggested that the over-expression of cAMP-activated $\mathrm{Na} / \mathrm{Ca}$ exchange in the reverse mode in the cell membrane of soft tissues could serve as an early diagnostic marker for carcinogenesis and that over-hydration of tumor cells is due to the increase of water permeability in the membrane as a result of abnormal increase of $\left[\mathrm{Ca}^{2+}\right]_{i}$.
\end{abstract}

Keywords: Tumor; Hydration; $\mathrm{Na} / \mathrm{Ca}$ exchange; Brain cortex; Spleen tissue

\section{Introduction}

The metabolic control of cell hydration serves as a quantummechanical sensitive cell parameter determining the functional activity of the cell, which is realized through the surface-dependent changes of the number of functionally active membrane proteins, having enzymes [1], receptors [2] and ionic channel-forming properties [3], as well as through hydration-dependent regulation of intracellular macromolecules' activity by folding-unfolding mechanism [4]. Therefore, the dysfunction of metabolic control of cell hydration can be considered as a common consequence of any cell pathology. However, the cell over-hydration serves as a diagnostic marker for carcinogenesis [5], while the cell dehydration-as a marker for nerve and cardiovascular disorders [6]. The data indicate that different metabolic pathways control the cell hydration in excitable and soft tissues. From the diagnostic point of view, it is important to evaluate which of these two types of tissue hydration is more sensitive to pathology of organism, including carcinogenesis.
Previously, we have shown that the cyclic nucleotide-dependent $\mathrm{Na} / \mathrm{Ca}$ exchange, which has a crucial role in the regulation of intracellular Ca homeostasis $\left.\left(\mathrm{Ca}^{2+}\right]_{\mathrm{i}}\right)$ serves as a quantum-mechanical sensor through which the biological effects of extremely weak physical and chemical signals on the cells and organism are realized [7-10]. It has also been shown that the cGMP-dependent $\mathrm{Na} / \mathrm{Ca}$ exchange in the forward $(F)$ mode reverses into cAMP-dependent $\mathrm{Na} / \mathrm{Ca}$ exchange in the reverse $(\mathrm{R})$ mode depending on ageing. The cGMP-dependent $\mathrm{FNa} / \mathrm{Ca}$ exchange can be stimulated by $\mathrm{pM}$ ouabain, while the cAMP-dependent $\mathrm{RNa} / \mathrm{Ca}$ exchange by $\mathrm{nM}$ ouabain $[11,12]$. Although, the $\mathrm{Na} / \mathrm{Ca}$ exchange functions in stoichiometry of $3 \mathrm{Na}: 1 \mathrm{Ca}$, its effect on cell hydration depends on the initial state of organisms: in the young animals the activation of cGMP-dependent $\mathrm{FNa} / \mathrm{Ca}$ exchange leads to cell dehydration, while in the old animals the activation of cAMP-dependent $\mathrm{RNa}$ / Ca exchange leads to cell hydration. So they have hydration and dehydration effects on cell, respectively $[13,10]$. 
On the basis of the mentioned age-dependent dysfunction of intracellular signaling system leading to $\mathrm{RNa} / \mathrm{Ca}$ exchange-induced dehydration has been suggested as a primary cellular mechanism for the pathology of nerve and cardiovascular systems [14]. However, the role of cyclic nucleotide-dependent $\mathrm{Na} / \mathrm{Ca}$ exchange in regulation of cell hydration in norm and pathology in soft tissues, including cancer tissues is not clear yet. Therefore, the aim of the present work is to evaluate the role of cAMP-dependent $\mathrm{RNa} / \mathrm{Ca}$ exchange in generation of cell pathology in soft tissues. For this purpose, the comparative study of brain cortex, spleen and tumor tissue hydrations, $\left[{ }^{3} \mathrm{H}\right]-$ ouabain binding with cell membrane, the ${ }^{45} \mathrm{Ca}^{2+}$ uptake by cells and intracellular cAMP contents in healthy $(\mathrm{H})$ and tumor carrying (TC) mice has been performed.

\section{Materials and Methods}

\section{Animals}

All the procedures performed on animals were carried out following the protocols approved by Animal Care and Use Committee of Life Sciences International Postgraduate Educational Centre (LSIPEC, Yerevan, Armenia). Albino white male mice with the average weight of $18-20 \mathrm{~g}$ were used for the experiments. The experiments were performed on 300 male albino mice $(150 \mathrm{H}$ and $150 \mathrm{TC})$. They were regularly examined, kept under control of the veterinary in LSIPEC and reserved in a specific pathogen-free animal room under optimum conditions of $12 \mathrm{~h} \mathrm{light/dark} \mathrm{cycles,} \mathrm{at} \mathrm{the} \mathrm{temperature} \mathrm{of} 22 \pm 2^{\circ} \mathrm{C}$, with a relative humidity of $50 \%$ and were fed ad libitum on a standard lab chow and water.

\section{Chemicals}

Tyrode's physiological solution (PS) containing (in $\mathrm{mM}$ ) $137 \mathrm{NaCl}$, $5.4 \mathrm{KCl}, 1.8 \mathrm{CaCl}_{2}, 1.05 \mathrm{MgCl}_{2}, 5 \mathrm{C}_{6} \mathrm{H}_{12} \mathrm{O}_{6}, 11.9 \mathrm{NaHCO}_{3}$, and 0.42 $\mathrm{NaH}_{2} \mathrm{PO}_{4}$, adjusted to $\mathrm{pH} 7.4$ with $\mathrm{NaOH}$ was used. All the chemicals were obtained from "Medisar" Industrial Chemical Importation Company (Yerevan, Armenia). The $\left[{ }^{3} \mathrm{H}\right]$-ouabain with specific activity $(25.34 \mathrm{Ci} / \mathrm{mM})$ and non-radioactive ouabain (PerkinElmer, Massachusetts, USA) from $10^{-9} \mathrm{M}$ to $10^{-4} \mathrm{M}$ concentrations dissolved in the PS were used for intraperitoneal (i.p) injection and incubation. The volume of injected solutions was adjusted according to the weight of the animals $(0.02 \mathrm{ml} / \mathrm{g})$, the samples were incubated in $10 \mathrm{ml}$ of experimental solution.

\section{Tissue preparation}

It is well known that anesthetics with different chemical and pharmacological profiles significantly affect metabolic processes, which play an important role in the regulation of cell volume $[15,16]$. Therefore, in the present experiments animals were sharply immobilized by freezing method (dipping their noses into liquid nitrogen for 3-4 sec) and decapitated [16]. After such a procedure the full absence of somatic reflexes on extra stimuli was recorded. For each experimental group 15 animals were chosen. The tissues of brain cortex, spleen and tumor were isolated and 3 samples from each animal were taken. The weight of each sample was from 50 to $60 \mathrm{mg}$. Thus, in each experimental group the number of tissue slices was 45 .

\section{Definition of water content of tissues}

Water content of tissue was determined by traditional "tissue drying" method [17]. After measuring the wet weight (w.w.) of a tissue it was dried in oven (Factory of Medical Equipment, Odessa, Ukraine) for $24 \mathrm{~h}$ at $105^{\circ} \mathrm{C}$ for determination of dry weight (d.w.). The quantity of water in $1 \mathrm{~g}$ of d.w. tissue was counted by the following equation: (w.w-d.w.)/d.w.

\section{Counting of $\left[{ }^{3} \mathrm{H}\right]$-ouabain receptors in membrane}

To estimate the number of $\mathrm{Na}^{+} / \mathrm{K}^{+}$-ATPase molecules in membrane, the number of $\left[{ }^{3} \mathrm{H}\right]$-ouabain molecules binding with cell membrane was counted. In the in vivo experiments $\left[{ }^{3} \mathrm{H}\right]$-ouabain was i.p injected to animals. After $30 \mathrm{~min}$. animals were sacrificed and the brain cortex, spleen and tumor tissue slices were dissected and incubated in the $100 \mathrm{ml}$ ouabain-free PS. To remove surface-adherent and extracellular tracer the brain cortex, spleen and tumor tissue slices were washed fivefold; each wash was about $5 \mathrm{~min}$ in duration, in the normal (ouabain-free) PS. After determination of wet and dry weight of samples, they were homogenized in $50 \mu \mathrm{l}$ of $68 \% \mathrm{HNO}_{3}$ solution. Then $2 \mathrm{ml}$ of Bray's scintillation fluid was added and radioactivity of samples was quantified with Wallac-1450 Liquid Scintillation and Luminescence Counter (Pribori Oy, Turku, Finland). The number of ouabain molecules binding with cell membranes was defined per mg of dry weight of samples.

\section{Measurement of ${ }^{45} \mathrm{Ca}^{2+}$ uptake}

The $45 \mathrm{Ca}^{2+}$ uptake was measured by the following way: 0.0115 $\mathrm{mM} \mathrm{CaCl}$ from $1.8 \mathrm{mM}$ was substituted by radioactive ${ }^{45} \mathrm{Ca}^{2+}(11.2$ $\mathrm{mCi} / \mathrm{l}$ ) in the PS. Animals were i.p injected with ${ }^{45} \mathrm{Ca}^{2+}$ (with 0.187 $\mathrm{mCi} / \mathrm{g}$ radioactivity of body weight) dissolved in the PS. After $30 \mathrm{~min}$. animals were decapitated and the brain cortex, spleen and tumor tissue samples were incubated for $30 \mathrm{~min}$. in the PS (as a control) and the PS once containing $10^{-9} \mathrm{M}$ and once $10^{-4} \mathrm{M}$ ouabain. Then all the samples were dried in thermostat during $24 \mathrm{~h}$ at $105^{\circ} \mathrm{C}$. The quantity of ${ }^{45} \mathrm{Ca}^{2+}$ uptake by the brain cortex, spleen and tumor tissue sample slices was expressed by $\mathrm{cpm} / \mathrm{mg}$ d.w.

\section{Determination of cAMP content in the samples}

Determination of cAMP content in the samples was performed according to the cAMP $\left.{ }^{[125} \mathrm{I}\right]$ RIA KIT manual (PerkinElmer Life sciences, Inc.). Precipitation of proteins from tissues has been accomplished with trichloroacetic acid (TCA). Frozen tissue samples were homogenized at $4^{\circ} \mathrm{C}$ with $6 \%$ TCA to make a $1 \mathrm{~mL} 10 \%(\mathrm{w} / \mathrm{v})$ homogenate. Equal volume of cold 10\% TCA was added supernatants. TCA extracts were centrifuged at $2,500 \times \mathrm{g}$ at $4^{\circ} \mathrm{C}$ for $15 \mathrm{~min}$. The supernatant was collected and extracted 4 times with $5 \mathrm{x}$ volume of water-saturated ether. After this the ether phase was discarded. Later, the samples were placed in the water bath at $70-80^{\circ} \mathrm{C}$ and evaporated to dryness under a stream of air. The residue was dissolved in Assay Buffer and $100 \mu \mathrm{L}$ of this solution was used directly in the Assay. Counting of the samples was performed by Wallac-1450 liquid scintillation and luminescence counter (Pribori Oy, Turku, Finland). The concentration of cAMP in the samples was determined by interpolation from the standard curve.

\section{Statistic analysis}

Microsoft Excel and Sigma-Plot (Version 8.02A, NY, and USA) were used for data analyses. Significance in comparison with the sham group was calculated with Student's paired t-test with the following symbols $\left({ }^{*} \mathrm{p}<0.05 ;{ }^{* *} \mathrm{p}<0.01 ;{ }^{* *} \mathrm{p}<0.001\right)$.

\section{Results}

The comparative study of tissue hydration of $\mathrm{H}$ and TC mice has shown that the level of hydration in brain cortex and spleen tissues in TC mice is higher than in $\mathrm{H}$ mice (Table 1). It is worth to note that the differences between tissue hydrations of $\mathrm{H}$ and $\mathrm{TC}$ mice are more pronounced in spleen tissues (5.8\%) than in brain cortex tissues (3.9\%). Each datum is the average value of 45 pieces. 
Table 1: The cell hydration of brain cortex and spleen tissues in healthy $(\mathrm{H})$ and tumor carrying (TC) mice in ouabain-free and $10^{-4} \mathrm{M}$ ouabain containing physiological solution (PS).

\begin{tabular}{|c|c|c|c|c|c|c|}
\hline \multicolumn{7}{|c|}{ Water content g/g d.w. } \\
\hline \multicolumn{4}{|c|}{ Brain cortex } & \multicolumn{3}{|c|}{ Spleen } \\
\hline Ouabain Dose M & Healthy & Tumor carrying & $\mathrm{H} / \mathrm{TC} \Delta \mathbf{2} \%$ & Healthy & Tumor carrying & $\mathrm{H} / \mathrm{TC} \Delta 2 \%$ \\
\hline 0 & 4.64 & 4.82 & $\begin{array}{c}3.9 \\
p<0.05 \\
*\end{array}$ & 3.45 & 3.65 & $\begin{array}{c}5.8 \\
p<0.05 \\
*\end{array}$ \\
\hline $10^{-4}$ & 5.47 & 4.17 & $\begin{array}{c}23.8 \downarrow \\
\mathrm{p}<0.001 \\
* * *\end{array}$ & 3.8 & 3.45 & $\begin{array}{c}9.2 \downarrow \\
\mathrm{p}<0.001 \\
* * *\end{array}$ \\
\hline$\Delta_{1} \%$ & $\begin{array}{c}17.9 \\
p<0.001 \\
* * *\end{array}$ & $\begin{array}{c}13.5 \downarrow \\
\mathrm{p}<0.001 \\
* * *\end{array}$ & - & $\begin{array}{c}10.1 \\
p<0.001 \\
* * *\end{array}$ & $\begin{array}{c}5.5 \downarrow \\
\mathrm{p}<0.05 \\
*\end{array}$ & - \\
\hline
\end{tabular}

To estimate the role of $\mathrm{Na}^{+} / \mathrm{K}^{+}$pump in the increase of brain cortex and spleen tissue hydration of TC mice, the effect of $10^{-4} \mathrm{M}$ ouabain on tissue hydration as well as the $\left[{ }^{3} \mathrm{H}\right]$-ouabain binding with cell membrane of these tissues in $\mathrm{H}$ and TC mice have been studied.

As the data present, the $10^{-4} \mathrm{M}$ ouabain-induced inhibition of $\mathrm{Na}^{+} / \mathrm{K}^{+}$pump activity [18] increases the hydration in brain cortex and spleen tissues of $\mathrm{H}$ mice by $17.9 \%$ and $10.1 \%$, respectively, and brings to dehydration by $13.5 \%$ and $5.5 \%$ in TC mice. The obtained data indicate that the $\mathrm{Na}^{+} / \mathrm{K}^{+}$pump inhibition-induced hydration and dehydration of tissues in $\mathrm{H}$ and TC mice are more significantly expressed in brain cortex than in spleen tissues. Although, the $10^{-4} \mathrm{M}$ ouabain leads to cell dehydration in brain cortex and spleen tissues of TC mice, the $\left[{ }^{3} \mathrm{H}\right]$-ouabain binding with cell membrane of these tissues is increased by $5.6 \%$ and $2.7 \%$ respectively, as compared with $\left[{ }^{3} \mathrm{H}\right]$-ouabain binding with those tissues of $\mathrm{H}$ mice (Table 2).

The next ion-transporting mechanism in membrane, which functions in electrogenic regime and is involved in the regulation of cell hydration, is $\mathrm{Na} / \mathrm{Ca}$ exchange [8]. It is known that the $\mathrm{Na}^{+} / \mathrm{K}^{+}$ pump inactivation leads to $\mathrm{RNa} / \mathrm{Ca}$ exchange as a result of $\left[\mathrm{Na}^{+}\right]_{i}$ increase [19].

Our previous study has shown that nM ouabain, which has no effect on the $\mathrm{Na}^{+} / \mathrm{K}$ pump activity stimulates $\mathrm{RNa} / \mathrm{Ca}$ exchange also by the increase of intracellular contents of cAMP [20]. It indicates that $\mathrm{nM}$ ouabain-induced activation of cAMP-dependent $\mathrm{RNa} / \mathrm{Ca}$ exchange has hydration effects on the brain cortex and heart tissues of young animals while in case of old animals it has dehydration effects on the same tissues [21]. To evaluate the role of cAMP-dependent $\mathrm{RNa} / \mathrm{Ca}$ exchange in tissue hydration in TC mice compared with tissues of $\mathrm{H}$ mice, the protocol of previous experiments with $10^{-4} \mathrm{M}$ ouabain and $\left[{ }^{3} \mathrm{H}\right]$-ouabain binding with cell membrane has been repeated at $10^{-9} \mathrm{M}$ ouabain concentration.

The data presented in table 3 indicate that as in case of the impact of $10^{-4} \mathrm{M}$ ouabain, the $10^{-9} \mathrm{M}$ ouabain also leads to hydration in the brain cortex and spleen tissues of $\mathrm{H}$ mice and dehydration in TC mice (Table 3). However, unlike the $10^{-4} \mathrm{M}$ ouabain effect, the $\mathrm{nM}$ ouabain-induced hydration effect is more pronounced on the spleen tissues (4.4\%) than on the brain cortex tissues (3.9\%), while in the tissues of TC mice the $10^{-9} \mathrm{M}$ ouabain has more pronounced dehydration effect on the brain cortex tissues (6.4\%) than on the spleen tissues (4.1\%).
The study of $10^{-9} \mathrm{M},\left[{ }^{3} \mathrm{H}\right]$-ouabain binding with cell membrane has shown that although the $10^{-9} \mathrm{M}$ oubain in TC mice has dehydration effects on the brain cortex and spleen tissues, the number of $\left[{ }^{3} \mathrm{H}\right]-$ ouabain binding with cell membrane of the brain cortex tissues is not changed, in the spleen tissues it is dramatically increased (67\%), compared with $\left[{ }^{3} \mathrm{H}\right]$-ouabain binding with the membrane of spleen cells of $\mathrm{H}$ animals (Table 4).

Previously it has been shown that $\mathrm{nM}$ ouabain in excitable cells has stimulation effect on $\mathrm{RNa} / \mathrm{Ca}$ exchange $[20,21]$. In order to evaluate the role of $\mathrm{RNa} / \mathrm{Ca}$ exchange regulation of $\left[\mathrm{Ca}^{2+}\right]_{i}$ of spleen tissues of TC mice, in the next series of experiments the study of the effects of $10^{-4} \mathrm{M}$ and $10^{-9} \mathrm{M}$ ouabain on the ${ }^{45} \mathrm{Ca}^{2+}$ uptake by the brain cortex and spleen tissues in $\mathrm{H}$ and TC mice have been performed.

As can be seen in figure 1, in both brain cortex and spleen tissues of TC mice the ${ }^{45} \mathrm{Ca}^{2+}$ uptake in ouabain-free medium is significantly higher than in $\mathrm{H}$ animals. The $10^{-9} \mathrm{M}$ and $10^{-4} \mathrm{M}$ ouabain have activation effects on the ${ }^{45} \mathrm{Ca}^{2+}$ uptake in both brain cortex and spleen tissues, where the $10^{-9} \mathrm{M}$ effects are more pronounced than $10^{-4} \mathrm{M}$ ouabain effects (Figures $1 \mathrm{~A}, 1 \mathrm{C}$ ). In the brain cortex tissues of TC mice both $10^{-9} \mathrm{M}$ and $10^{-4} \mathrm{M}$ ouabain concentrations have similar depressing effects on the ${ }^{45} \mathrm{Ca}^{2+}$ uptake compared with ouabainfree medium (Figure 1B). However, in spleen cells of TC mice the ouabain sensitivity of the ${ }^{45} \mathrm{Ca}^{2+}$ uptake is not significantly changed compared with the ${ }^{45} \mathrm{Ca}^{2+}$ uptake in $\mathrm{H}$ mice (Figure 1D).

As can be seen in figure 1, in both brain cortex and spleen tissues of TC mice the ${ }^{45} \mathrm{Ca}^{2+}$ uptake in ouabain-free medium is significantly higher than in $\mathrm{H}$ animals. The $10^{-9} \mathrm{M}$ and $10^{-4} \mathrm{M}$ ouabain have activation effects on the ${ }^{45} \mathrm{Ca}^{2+}$ uptake in both brain cortex and spleen tissues, where the $10^{-9} \mathrm{M}$ effects are more pronounced than $10^{-4} \mathrm{M}$ ouabain effects (Figure 1A,1C). In the brain cortex tissues of TC mice both 10 ${ }^{9} \mathrm{M}$ and $10^{-4} \mathrm{M}$ ouabain concentrations have similar depressing effects on the ${ }^{45} \mathrm{Ca}^{2+}$ uptake compared with ouabain-free medium (Figure 1B). However, in spleen cells of TC mice the ouabain sensitivity of the ${ }^{45} \mathrm{Ca}^{2+}$ uptake is not significantly changed compared with the ${ }^{45} \mathrm{Ca}^{2+}$ uptake in $\mathrm{H}$ mice (Figure 1D).

As it has been shown previously the nM ouabain-induced activation of $\mathrm{RNa} / \mathrm{Ca}$ exchange in neuronal and muscle cells is realized by activation of cAMP formation, which has an age-weakening character 
Table 2: The $\left[{ }^{3} \mathrm{H}\right]$-ouabain binding with cell membrane in brain cortex and spleen tissues of healthy $(\mathrm{H})$ and tumor carrying (TC) mice at presence of $10^{-4} \mathrm{M}$ ouabain in physiological solution (PS). Each datum is the average value of 45 pieces.

\begin{tabular}{|c|c|c|c|c|c|c|}
\hline \multicolumn{9}{|c|}{ Number of ouabain molecules $\left({ }^{*} 10^{8}\right)$} \\
\hline Buabain Dortex $M$ & Healthy & Tumor carrying & $\Delta \%$ & Healthy & Tumor carrying & $\Delta \%$ \\
\hline $10^{-4}$ & 41764 & 44117 & $\begin{array}{c}5.6 \\
p<0.05 \\
*\end{array}$ & 42920 & 44080 & $\begin{array}{c}2.7 \\
p<0.05 \\
*\end{array}$ \\
\hline
\end{tabular}

Table 3: The effect of $10^{-9} \mathrm{M}$ ouabain on hydration in brain cortex and spleen tissues of healthy $(\mathrm{H})$ and tumor carrying (TC) mice. Each datum is the average value of 45 pieces.

\begin{tabular}{|c|c|c|c|c|c|c|}
\hline \multicolumn{7}{|c|}{ Water content g/g d.w. } \\
\hline \multicolumn{4}{|c|}{ Brain cortex } & \multicolumn{3}{|c|}{ Spleen } \\
\hline Ouabain Dose M & Healthy & Tumor carrying & $\mathrm{H} / \mathrm{TC} \Delta \mathbf{2} \%$ & Healthy & Tumor carrying & $\mathrm{H} / \mathrm{TC} \Delta \mathbf{2} \%$ \\
\hline 0 & 4.64 & 4.82 & $\begin{array}{c}3.9 \\
\mathrm{p}<0.05 \\
*\end{array}$ & 3.45 & 3.65 & $\begin{array}{c}5.8 \\
\mathbf{p}<0.05 \\
*\end{array}$ \\
\hline $10^{-9}$ & 4.82 & 4.51 & $\begin{array}{c}6.4 \downarrow \\
\mathrm{p}<0.01 \\
* *\end{array}$ & 3.6 & 3.5 & $\begin{array}{l}2.8 \downarrow \\
p>0.1\end{array}$ \\
\hline$\Delta_{1} \%$ & $\begin{array}{c}3.9 \\
p<0.05 \\
*\end{array}$ & $\begin{array}{c}6.4 \downarrow \\
p<0.001 \\
* * *\end{array}$ & - & $\begin{array}{c}4.4 \\
p<0.001 \\
* * *\end{array}$ & $\begin{array}{l}4.1 \downarrow \\
p>0.1\end{array}$ & - \\
\hline
\end{tabular}

$[13,22]$. To find out whether in spleen cells the activation of $\mathrm{RNa} / \mathrm{Ca}$ exchange is correlated with elevation of cAMP so as in excitable cells, in the next series of experiments we have studied the intracellular cAMP contents in the brain cortex and spleen cells in $\mathrm{H}$ and TC mice in ouabain-free medium as well as in the PS containing $10^{-4} \mathrm{M}$ and $10^{-9} \mathrm{M}$ ouabain.

Figure 2 show that $\mathrm{nM}$ ouabain has elevation effect on the intracellular contents of cAMP in both brain cortex and spleen tissues of $\mathrm{H}$ animals, which is depressed in TC mice. But it is interesting to note that the $10^{-4} \mathrm{M}$ ouabain has no significant effect on cAMP contents in the brain cortex tissues of $\mathrm{H}$ mice, while in TC mice it has a slight elevation effect. In the spleen cells the $10^{-4}$ $M$ ouabain has the same activation effect on cAMP contents in both $\mathrm{H}$ and $\mathrm{TC}$ mice.

The presented data on the ${ }^{45} \mathrm{Ca}^{2+}$ uptake and cAMP contents clearly indicate that different signaling systems control cell hydration in the brain cortex and spleen tissues in norm and pathology. The investigation of the nature of these mechanisms is the subject of our current studies.

In the next series of experiments the effects of $10^{-9} \mathrm{M}$ and $10^{-4} \mathrm{M}$ ouabain on the hydration of tissues of TC mice, the ${ }^{45} \mathrm{Ca}^{2+}$ uptake and cAMP contents have been studied.

As figure $3 \mathrm{~A}$ shows, both concentrations of ouabain bring to tissue hydration in TC animals. However, the stimulation effect of $10^{-}$ ${ }^{9} \mathrm{M}$ ouabain on ${ }^{45} \mathrm{Ca}^{2+}$ uptake is more pronounced $(13.0 \%)$ than the effect of $10^{-4} \mathrm{M}$ ouabain (0.43\%) (Figure 3B). It is interesting to note that in case of the ${ }^{45} \mathrm{Ca}^{2+}$ uptake $10^{-9} \mathrm{M}$ ouabain there is an elevation of intracellular cAMP contents figure $3 \mathrm{C}$, while $10^{-4} \mathrm{M}$ ouabain has no significant effect on it compared with ouabain-free medium.

\section{Discussion and Conclusion}

It is known that although the cell membrane is highly permeable for water, the intracellular osmotic pressure exceeds the extracellular one because of the existence of metabolic mechanism(s), which pump water from the cell. Our previous study has shown that in the membrane of neurons and myocytes the $\mathrm{Na}^{+} / \mathrm{K}^{+}$pump besides controlling intracellular ionic homeostasis (cell hydration), has also depressing effects on the membrane permeability for inward ionic currents by two mechanisms: by the surface-dependent decrease of the number of functionally active ionic channels in the membrane and by the inactivation of ionic channels for inward ionic currents through the generation of net water efflux from the cells $[23,3]$.

The $\mathrm{Na}^{+} / \mathrm{K}^{+}$pump in excitable cells has a key role in generation of water efflux from the cells: it produces water efflux from the cell by generating osmotic gradients on the membrane, because of its stoichiometry of $3 \mathrm{Na}^{+}: 2 \mathrm{~K}^{+},[24,25]$ and it, being a highly ATP utilizing machine in the membrane by stimulation of intracellular oxidative processes releases water molecules in cell cytoplasm. Thus, in the excitable cells the $\mathrm{Na}^{+} / \mathrm{K}^{+}$pump have double effects on the cell hydration: on the one hand, it has dehydration effect because of its electrogenic character and properties to inhibit inward currents and on the other hand, it has hydration effect on cells by activation of intracellular oxidative process-induced release of water molecule in the cell.

It is known that unlike excitable cells, non-excitable cells have highly expressed cell volume recovery systems, which indicates the high 

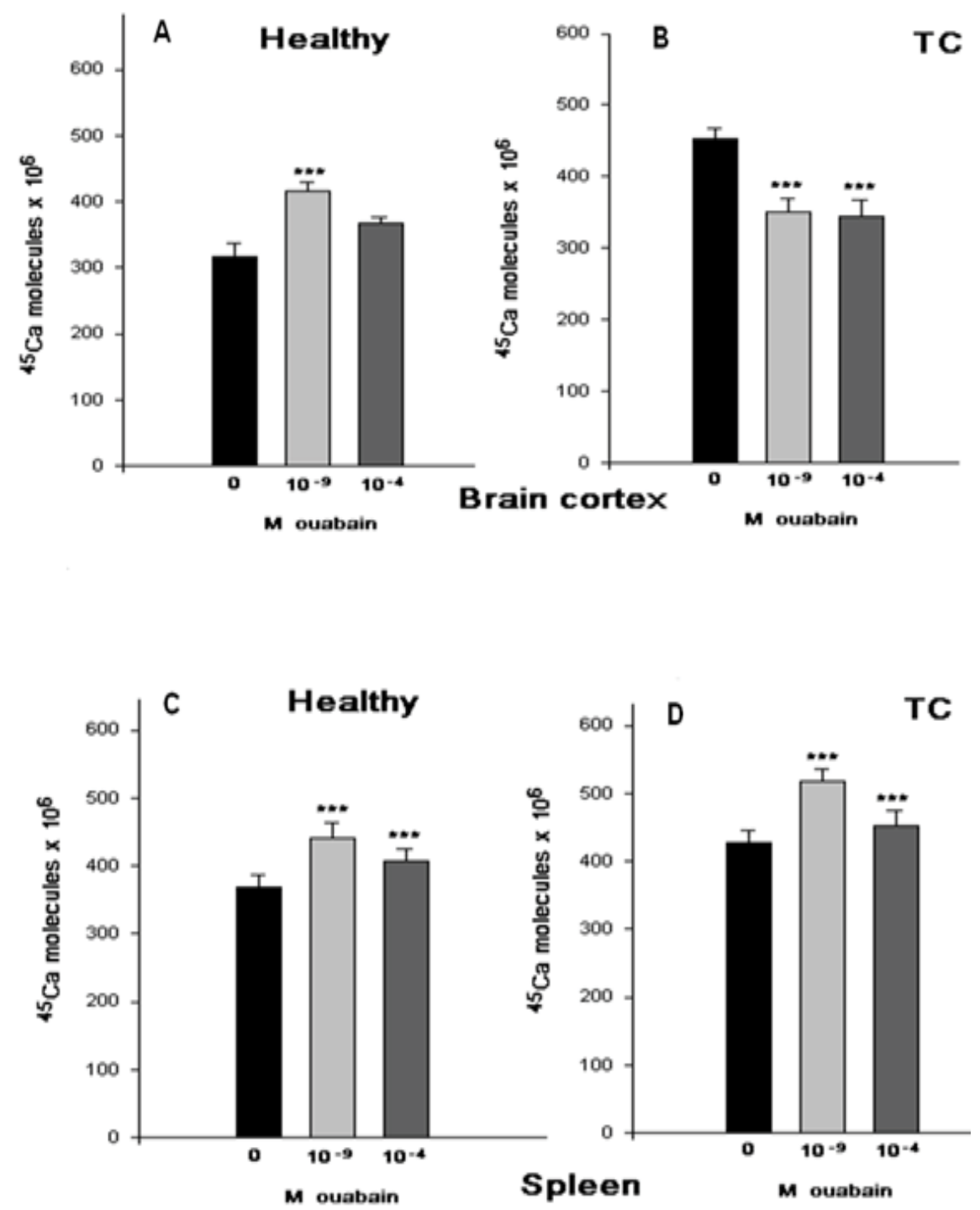

Figure 1: The ${ }^{45} \mathrm{Ca}^{2+}$ uptake in in vitro experiments was determined after $30 \mathrm{~min}$. incubation of ouabain-free and ouabain-containing $\left(10^{-9} \mathrm{M}\right.$ and $10^{-4} \mathrm{M}$ ) PS in healthy (H) and tumor carrying (TC) mice. The size of columns indicates that the ${ }^{45} \mathrm{Ca}^{2+}$ uptake by tissue expressed in Cpm/mg dry weight. Under each pair of columns corresponding ouabain concentrations are noted. The ${ }^{45} \mathrm{Ca}^{2+}$ uptake by brain cortex $\mathrm{A}\left(10^{-9}\right.$ is $34.4 \%$ and $10^{-4}$ is $18.8 \%)$ and $B\left(10^{-9}\right.$ is $20 \%$ and $10^{-4}$ is $\left.22 \%\right)$, spleen tissues $C\left(10^{-9}\right.$ is $20.5 \%$ and $10^{-4}$ is $\left.10.3 \%\right)$ and $D\left(10^{-9}\right.$ is $24.4 \%$ and $10^{-4}$ is $\left.6.5 \%\right)$ of healthy $(\mathrm{H})$ and tumor carrying (TC) mice. Error bars indicate the standard error of the mean \pm SEM of 45 samples. The symbols $\left({ }^{* * *}\right)$ indicate $p<0.001$, respectively. The experiments were carried out at the room temperature $\left(22^{\circ} \mathrm{C}\right)$.

permeability of the membrane for water [26]. Therefore, in soft tissues the $\mathrm{Na}^{+} / \mathrm{K}^{+}$pump could not have significant dehydration effect on cells because of depressing electrogenic properties of the $\mathrm{Na}^{+} / \mathrm{K}^{+}$pump making it unable to generate osmotic gradients on the membrane.

The data that tissue hydration is higher in TC mice than in $\mathrm{H}$ mice table 1 can be explained by the increase of the osmotic water uptake as a result of the impairment of metabolic water efflux from the cells or by generation of endogenous water as a result of the activation of metabolic activity of cells in response to the impact of carcinogenic factors on the cells. The evidence that $10^{-4} \mathrm{M}$ ouabain-induced pump inhibition leads to tissue dehydration in TC mice indicates the increase of metabolic nature of tissue hydration in TC mice compared with $\mathrm{H}$ mice. And, finally, the fact that in TC mice the spleen tissue hydration has been increased twice more than in the brain cortex tissues table 1 can be explained by the absence of dehydration effect of the $\mathrm{Na}^{+} / \mathrm{K}^{+}$ pump in the spleen cells.

Our earlier study has shown that cell hydration leads to the increase of ouabain receptors' number in membrane [1]. However, the achieved results table 2 shows that in TC mice $10^{-4} \mathrm{M}$ ouabaininduced tissue dehydration is accompanied with the increase of $\left[{ }^{3} \mathrm{H}\right]$-ouabain binding with the cell membrane compared with $\left[{ }^{3} \mathrm{H}\right]$-ouabain binding with the cell membrane in tissues of $\mathrm{H}$ animals. Therefore, such opposite dynamics of ouabain-induced cell dehydration with the increase of receptor binding sites in the membrane can be explained by the increased expression of new receptors in the cell membrane of TC mice. 
It is known that the inhibition of electrogenic $\mathrm{Na}^{+} / \mathrm{K}^{+}$pump leads to the activation of $\mathrm{RNa} / \mathrm{Ca}$ exchange, which is traditionally explained by the increase of $\left[\mathrm{Na}^{+}\right]_{\mathrm{i}}[19,27]$. However, our studies have shown that such an opposite correlation between $\mathrm{Na}^{+} / \mathrm{K}^{+}$pump and $\mathrm{Na} /$ Ca exchange is realized also by pump-induced increase of cAMP contents leading to activation of $\mathrm{RNa} / \mathrm{Ca}[28,8]$. Although, the $\mathrm{RNa} /$ $\mathrm{Ca}$ exchange functions in stoichiometry of $3 \mathrm{Na}: 1 \mathrm{Ca}$ it could have hydration or dehydration effect depending on initial functional activity of nerve and muscle. Our previous study has shown that nM ouabain-induced activation of $\mathrm{RNa} / \mathrm{Ca}$ exchange in the brain cortex tissues of young mice has more pronounced hydration effects than 10 ${ }^{4} \mathrm{M}$ ouabain-induced activation of $\mathrm{RNa} / \mathrm{Ca}$ exchange [13]. According to the literature, soft tissues are not expressed with the higher affinity isoforms ( $\alpha 3 / \alpha 2)$ of $\mathrm{Na}^{+} / \mathrm{K}^{+}$-ATPase $[29,30]$. The obtained data on $\mathrm{nM}$ sensitivity of spleen tissue hydration and the existence of their binding sides in the cell membrane of this tissue of $\mathrm{H}$ mice clearly indicate that besides $\mathrm{Na}^{+} / \mathrm{K}^{+}$-ATPase, ouabain has other receptors in membrane the activation of which leads to stimulation of $\mathrm{RNa} / \mathrm{Ca}$ exchange. The data that $\mathrm{nM}$ ouabain has hydration and dehydration effects on the brain cortex and spleen tissues in $\mathrm{H}$ and TC mice, respectively, indicate the metabolic nature, which can be due to the activation of $\mathrm{RNa} / \mathrm{Ca}$ exchange. It is worth to note that in $\mathrm{H}$ mice the $\mathrm{nM}$-induced hydration effect on spleen tissues is significantly higher (4.4\%) than in brain cortex tissues (3.9\%), while in TC mice the nM ouabain has more pronounced effect on the brain cortex tissues (6.4\%) than on the spleen tissues (4.1\%) (Table 3).

Despite the fact that $\mathrm{nM}$ ouabain brings to tissue hydration in $\mathrm{H}$ and dehydration in TC mice, the quantity of $\left[{ }^{3} \mathrm{H}\right]$-ouabain binding with the cell membrane of brain cortex tissues of TC mice is the same as in $\mathrm{H}$ animals, while in the spleen tissues of TC animals it is increased by $66.67 \%$ compared with the spleen tissues of $\mathrm{H}$ mice. Table 4 clearly indicates over-expression of nM ouabain receptor in the brain cortex and spleen tissues of TC mice. But the over-expression of these receptors is incomparably more pronounced on spleen tissues than on brain cortex tissues. It is worth to note that since the present experiments are performed on the slices of brain cortex tissues, in which besides neurons there are also glial cells, the data that the brain cortex tissue dehydration is not accompanied with the decrease of ouabain binding with membrane can probably be due to the increase of expression of ouabain receptors in glial cells, which have high proliferative activity and are very sensitive to brain cortex pathology [31]. Based on the result of the present experiment it is difficult to conclude on the nature of newly expressed ouabain receptors in the cell membrane, therefore, special investigation is needed to evaluate it.

Our previous experiments performed on the brain cortex and heart tissues of animals have shown that in young animals the $10^{-9} \mathrm{M}$ ouabain has more pronounced activation effect on $\mathrm{RNa} / \mathrm{Ca}$ exchange and tissue hydration than $10^{-4} \mathrm{M}$ ouabain effect compared with control tissues. In old animals, in case of both concentrations, ouabain has depressing effect on $\mathrm{RNa} / \mathrm{Ca}$ exchange and tissue hydration [13]. Figure 2 indicates that as in case of ageing, in TC mice there is a decrease of the ${ }^{45} \mathrm{Ca}^{2+}$ uptake (RNa/Ca exchange), while in the spleen cells ${ }^{45} \mathrm{Ca}^{2+}$ uptake is not changed significantly.

It is known that both low and high concentrations of oubain-induced activation of $\mathrm{Na} / \mathrm{Ca}$ exchange are accompanied with the intracellular cAMP contents. The nM ouabain elevates the intracellular cAMP by stimulation of G-protein in membrane [32], while $10^{-4} \mathrm{M}$ leads to the stimulation of cAMP synthesis by the increased intracellular ATP contents [28]. The obtained data in the present work point out that the brain cortex and spleen tissues of TC mice have increased the $\mathrm{nM}$ ouabain-sensitivity of cAMP contents, while $10^{-4} \mathrm{M}$ ouabain-sensitivity causes an increase in cAMP contents (Figure 2).

On the basis of literature evidence cAMP-induced activation of $\mathrm{RNa} /$ $\mathrm{Ca}$ exchange of $\mathrm{H}$ animals leading to cell hydration can be explained by the activation of cAMP dependent $\mathrm{Ca}^{2+}$ pump in the membrane of endoplasmatic reticulum (ER) pushing Ca from cytoplasm into the ER [32], which stimulates mitochondrial activity through the zones of Mitochondria Associated Membranes' close contact [33] and release of water molecules in cytoplasm. Therefore, the depression of $\mathrm{nM}$ ouabain-induced elevation effects on cAMP in brain cortex and spleen cells can be explained by losing Ca buffering properties of ER, leading to increase of $\left[\mathrm{Ca}^{2+}\right]_{\mathrm{i}}$ in cytoplasm.

The above mentioned cases allow us to speculate that the abnormal increase of $\left[\mathrm{Ca}^{2+}\right]_{\mathrm{i}}$ leads to cell dehydration by contraction of actin like proteins in neurons (cytoskeleton and myofibrils) and myosin in myocytes, while in soft tissues the increase of $\left[\mathrm{Ca}^{2+}\right]_{i}$ leads to cell hydration as a result of activation of lipase activity leading to increase membrane permeability for water. Our earlier work on hypotonic solution [1] as well as on breast cancer tissues [34] has shown an increased number of higher affinity ouabain receptors in membrane. Based on these data we consider the over-expression of nM-sensitive $\mathrm{Na} / \mathrm{Ca}$ exchanger in TC mice as a consequence of cell hydration of spleen. This suggestion supported by the obtained results on tumor tissues figure 3 where both low and high concentrations of ouabain have approximately same hydration effect on tumor tissue although the $\mathrm{nM}$ ouabain stimulation effect on $\mathrm{RNa} / \mathrm{Ca}$ exchange is more pronounced than $10-4 \mathrm{M}$ ouabain. This data can be explained by losing electrogenic effect of $\mathrm{RNa} / \mathrm{Ca}$ exchange because of high permeability membrane for water. It is interesting to note that tumor tissue still enables to generate cAMP and activate $\mathrm{RNa} / \mathrm{Ca}$ exchange upon the effect of $\mathrm{nM}$ ouabain. This phenomenon can be probably explained by the fact that still functioning of cAMPactivated in Ca pump on membrane of ER, pushing $\mathrm{Ca}$ from cytoplasm into $\mathrm{ER}$, which in its turn stimulates $\mathrm{RNa} / \mathrm{Ca}$ exchange in the cell membrane. Of course, this suggestion can be considered as a speculation and final conclusion can be done after more detailed investigation.

Thus, the obtained data in the present work brings us to the following conclusions:

- The transplantation of sarcoma-180 tumor in mice leads to the increase of hydration of the brain cortex and spleen tissues.

- Both high and low concentrations of ouabain have hydration effect on $\mathrm{H}$ and dehydration effects on TC mice.

- There is an increased expression of $\mathrm{nM}$ ouabain receptors in the cell membrane of spleen of TC mice leading to activation of $\mathrm{RNa}$ / Ca exchange by the independent mechanism of the $\mathrm{Na}^{+} / \mathrm{K}^{+}$pump.

- The cAMP contents in the brain cortex and spleen tissues of TC mice is dramatically decreased compared with those tissues of $\mathrm{H}$ animals.

- In the cell membrane of spleen tissues of TC mice there is an overexpression of $\mathrm{Na} / \mathrm{Ca}$ exchangers compared with the spleen tissues of $\mathrm{H}$ mice.

It is suggested that over-expression of $\mathrm{Na} / \mathrm{Ca}$ exchangers in soft tissues of the cell membrane could serve as a novel diagnostic marker for carcinogenesis. 

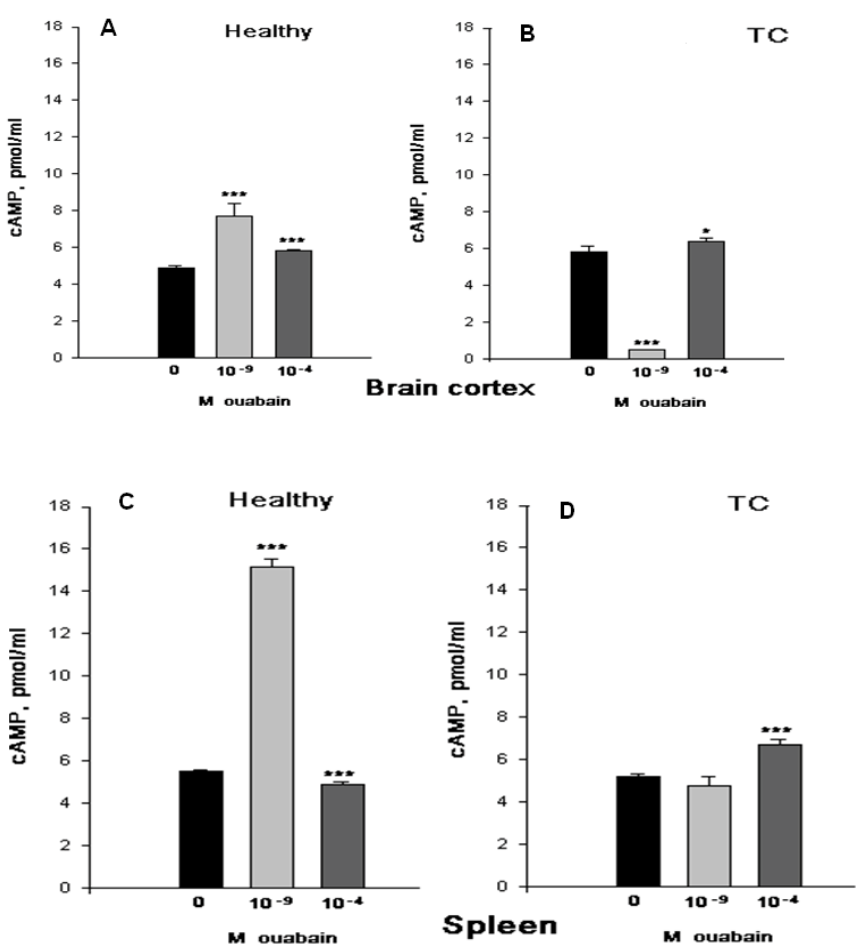

Figure 2: The effects of intraperitoneal (i.p) injection of Sham (black bars), of $10^{-9} \mathrm{M}$ (gray bars) and $10^{-4} \mathrm{M}$ (dark gray bars) ouabain on intracellular contents of cAMP in brain cortex (AB) and spleen (CD). cAMP in brain cortex $A\left(10^{-9}\right.$ is $66.7 \%$ and $10^{-4}$ is $\left.27.8 \%\right)$ and $B\left(10^{-9}\right.$ is $91.3 \%$ and $10^{-4}$ is $\left.8.7 \%\right)$, in spleen tissues $C\left(10^{-9}\right.$ is $168 \%$ and $10-4$ is $\left.9.2 \%\right)$ and $D(10-9$ is $8.3 \%$ and $10-4$ is $29.2 \%)$ of healthy $(H)$ and tumor carrying (TC) mice. Error bars indicate the standard error of the mean \pm SEM of 45 samples. The symbols $\left({ }^{*}\right)$ and $\left({ }^{* * *}\right)$ indicate $p<0.05$ and $p<0.001$, respectively. The experiments were carried out at the room temperature $\left(22^{\circ} \mathrm{C}\right)$.
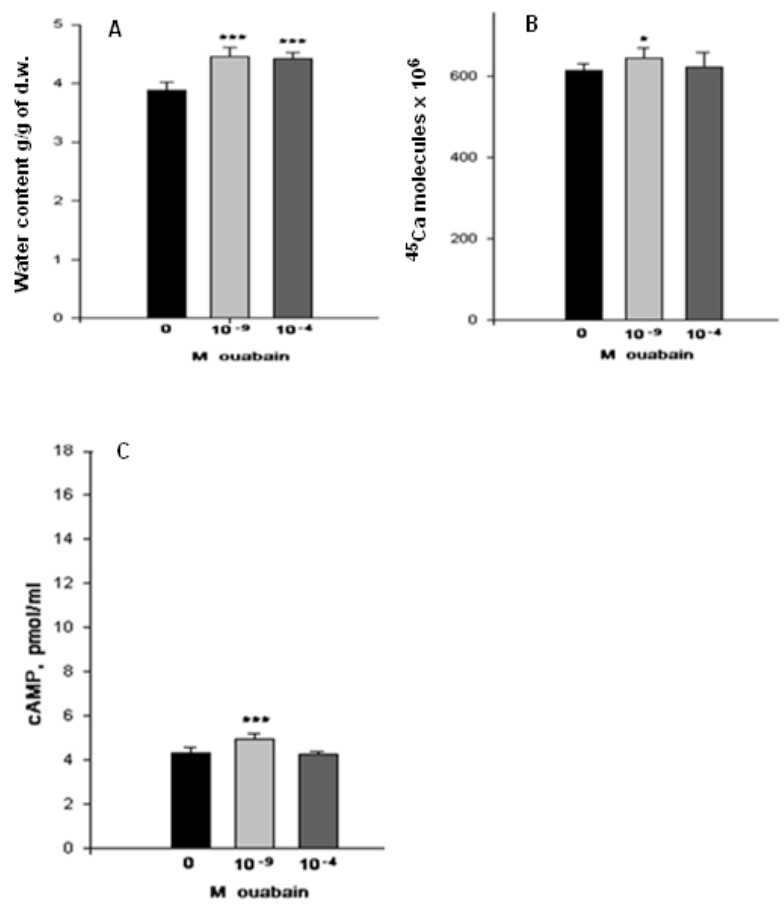

Figure 3: The effects of $10^{-9} \mathrm{M}$ and $10^{-4} \mathrm{M}$ ouabain on tumor tissue hydration (A), the ${ }^{45} \mathrm{Ca}^{2+}$ uptake (B), and cAMP content (C). Figure $3 \mathrm{~A}$ tumor tissue hydration $\left(10^{-9}\right.$ is $13.2 \%$ and $10^{-4}$ is $\left.11.3 \%\right)$, the ${ }^{45} \mathrm{Ca}^{2+}$ uptake Figure $3 \mathrm{~B}\left(10^{-9}\right.$ is $5.3 \%$ and $10^{-4}$ is $\left.1.8 \%\right)$, and cAMP content Figure $3 \mathrm{C}\left(10^{-9}\right.$ is $13.0 \%$ and $10^{-4}$ is $\left.0.43 \%\right)$. Error bars indicate the standard error of the mean \pm SEM of 45 samples. The symbols $\left({ }^{*}\right)$ and $\left({ }^{* * *}\right)$ indicate $p<0.05$ and $p<0.001$, respectively. The experiments were carried out at the room temperature $\left(22^{\circ} \mathrm{C}\right)$. 
Table 4: The ouabain binding with cell membrane in brain cortex and spleen tissues of healthy $(\mathrm{H})$ and tumor carrying (TC) mice at presence of $10^{-9} \mathrm{M}$ ouabain in the physiological solution (PS). Each datum is the average value of 45 pieces.

\begin{tabular}{|c|c|c|c|c|c|c|}
\hline \multicolumn{7}{|c|}{ Number of ouabain molecules $\left({ }^{*} 10^{8}\right)$} \\
\hline \multicolumn{4}{|c|}{ Brain cortex } & \multicolumn{3}{|c|}{ Spleen } \\
\hline Ouabain Dose M & Healthy & Tumor carrying & $\Delta \%$ & Healthy & Tumor carrying & $\Delta \%$ \\
\hline $10^{-9}$ & 5800 & 5800 & 0 & 8700 & 14500 & $\begin{array}{c}66.7 \\
\mathrm{p}<0.01 \\
* *\end{array}$ \\
\hline
\end{tabular}

\section{References}

1. Ayrapetyan SN, Suleymanyan MA, Saghyan AA, Dadalyan SS (1984) Autoregulation of the electrogenic sodium pump. Cell Mol Neurobiol 4: 367-383.

2. Ayrapetyan SN, Arvanov VL, Maginyan SB, Azatyan KV (1985) Further study of the correlation between Na-pump activity and membrane chemosensitivity. Cell Mol Neurobiol 5: 231-243.

3. Ayrapetyan SN, Rychkov GY, Suleymanyan MA (1988) Effects of Water Flow on Transmembrane Ionic Currents in Neurons of Helix Pomatia and in Squid Giant Axons. Comp Biochem Physiol 89: 179186.

4. Parsegian VA, Rand RP, Rau DC (2000) Osmotic Stress, Crowding, Preferential Hydration and Binding: A comparison of perspectives. Proc Nat Sci USA 97: 3987-3992.

5. Damadian R (1971) Tumor Detection by Nuclear Magnetic Resonance. Science 171: 1151-1153.

6. Lauriola M, Mangiacotti A, D'Onofrio G, Cascavilla L, Paris F, et al. (2018) Neurocognitive Disorders and Dehydration in Older Patients: Clinical Experience Supports the Hydromolecular Hypothesis of Dementia. Nutrients 10: 562-576.

7. Ayrapetyan SN, Carpenter DO (1991) Very low concentrations of acetylcholine and GABA modulate transmitter responses. Neuroreport 2: 563-565.

8. Ayrapetyan SN (2001) Na-K pump and Na:Ca exchanger as metabolic regulators and sensors for extraweak signals in neuromembrane. In: Ayrapetyan SN and North AC (eds) Modern problems of cellular and molecular biophysics, Noyan Tapan, Yerevan, 31-57.

9. Ayrapetyan G, Papanyan A, Hayrapetyan H, Ayrapetyan S (2005) Metabolic pathway of magnetized fluid-induced relaxation effects on heart muscle. Bioelectromagnetics 26: 624-630.

10. Ayrapetyan SN (2017) Reverse mode $\mathrm{Na}^{+} / \mathrm{Ca}^{+2}$ exchange induced cell dehydration as a primary mechanism for cell pathology. Glob Drugs Therap 2: 1-4.

11. Heqimyan A, Narinyan L, Nikoghosyan A, Deghoyan A, Yeganyan LR, et al. (2012) Age-dependency of high affinity ouabain receptors and their magneto sensitivity. The Environmentalist 32: 228-235.

12. Ayrapetyan S, Yeganyan L, Bazikyan G, Muradyan R, Arsenyan F (2012) Na/K Pump $\alpha 3$-Isoform-Dependent Cell Hydration Controlling Signaling System Dysfunction as A Primary Mechanism for Carcinogenesis. J Bioequiv Availab 4: 112-120.

13. Heqimyan AA, Narinyan LY, Nikoghosyan AK, Ayrapetyan SN (2015) In: Markov M (Ed.) Age-dependent magnetic sensitivity of brain and heart muscles. Electromagnetic Fields in Biology and Medicine, CRC Press, USA 217-230.
14. Ayrapetyan S (2015) The Dysfunction of Camp-Dependent $\mathrm{Na}^{+} /$ $\mathrm{Ca}^{2+}$ Exchange in Reverse Mode as a Primary Mechanism for AgeDependent Cardio-Muscle Failure. J Bioequiv Availab 8: 1-2.

15. Krnjevic K (1992) Cellular and synaptic actions of general anaesthetics. Gen Pharmacol 23: 965-975.

16. Takahashi R, Aprison M (1964) Acetylcholine content of discrete areas of the brain obtained by a near-freezing method. J Neurochem 11: 887-898.

17. Adrian RH (1956) The effect of internal and external potassium concentration on the membrane potential of frog muscle. J Physiol 133: 631-658.

18. Skou JC (1957) The influence of some cations on an adenosine triphosphatase from peripheral nerves. Biochim Biophys Acta 23: 394-401.

19. Baker PF, Blaustein MP, Hodgkin AL, Steinhardt SA (1969) The influence of calcium on sodium efflux in squid axons. J Physiol 200: 431-458.

20. Saghian AA, Ayrapetyan SN, Carpenter DO (1996) Low concentrations of ouabain stimulate $\mathrm{Na} / \mathrm{Ca}$ exchange in neurons. Cell Mol Neurobiol 16: 180-185.

21. Ayrapetyan SN, Heqimyan AA, Nikoghosyan AK (2012) Agedependent brain tissue hydration, $\mathrm{Ca}$ exchange and their dosedependent ouabain sensitivity. J Bioequiv Availab 4: 060-068.

22. Narinyan LY and Ayrapetyan SN (2017) Cyclik AMP-dependent signaling system is a primary metabolicmtarget for non-thermal effect of microwaves on heart muscle hydration. Electromagn Biol Med 36: 182-191.

23. Ayrapetyan SN (1980) On the physiological significance of the pump-induced cell volume changes. In: Salanki J (Eds). Advances in Physiological; Science: neurobiology of Invertebrates 23: 67-82.

24. Ayrapetyan SN, Sulejmanyan MA (1979) On the pump-induced cell volume changes. Comp Biochem Physiol 64: 571-575.

25. Carpenter PB, Mueller PR, Dunphy WG (1996) Role for a Xenopus Orc2-related protein in controlling DNA replication. Nature 379: 357-360.

26. Hoffmann P, Boeld TJ, Eder R, Huehn J, Floess S, et al. (2009) Loss of FOXP3 expression in natural human $C D 4+C D 25+$ regulatory $T$ cells upon repetitive in vitro stimulation. Eur J Immunol 39: 10881097.

27. Blaustein MP, Zhang J, Chen L, Song H, Raina H, et al. (2009) The pump, the exchanger, and endogenous ouabain: signaling mechanisms that link salt retention to hypertension. Hypertension 53: 291-298. 
28. Ayrapetyan SN, Carpenter DO, Azatian KV, Dadalian SS, Martirosyan DM, et al. (1992) Extra low neurotransmitter dozesinduced triggering of neuronal intracellular messanger systems. In: Kostyuk PG and Ostrovskii MA (eds.), Cellular Signalization, Nauka, Moscow, 89-96.

29. Blaustein NP, Lederer WJ (1999) Sodium/calcium exchange: its physiological implications. Physiol Rev 79: 763-854.

30. Xie Z, Askari A (2002) $\mathrm{Na}^{+} / \mathrm{K}^{+}$-ATPase as a signal transducer. Eur J Biochem 269: 2434-2439.

31. Jäkel S, Dimou L (2017) Glial Cells and Their Function in the Adult Brain. A Journey through the History of Their Ablation. Front Cell Neurosci 11: 24.
32. Brini M, Carafoli E (2009) Calcium pumps in health and disease. Physiol Rev 89: 1341-1378.

33. Venugopal J, Blanco G (2017) On the Many Actions of Ouabain: Pro-Cystogenic Effects in Autosomal Dominant Polycystic Kidney Disease. Molecules 22: 729.

34. Danielyan AA, Ayrapetyan SN (1999) Changes of hydration of rats' tissues after in vivo exposure to 0.2 Tesla steady magnetic field. Bioelectromagnetics 20: 123-128. 